\title{
On Studying the Interrelationships amongst the various Marketing and Advertising Performance Metrics for Architectural, Engineering and Construction Industry
}

\author{
P. K. Kapur \\ Amity Center for \\ Interdisciplinary Research \\ Amity University \\ Noida, India
}

\author{
Lakshay Aggarwal \\ Recventure Education \\ Services Private Limited \\ Delhi, India
}

\author{
Viraj Voditel \\ Techture Structures \\ Private Limited \\ Nagpur, India
}

\author{
Remica Aggarwal \\ Recventures Education \\ Services Private Limited, \\ Delhi, India
}

\begin{abstract}
Following research work focuses on exploring the possible challenges for solid waste management practices in developing countries such as India. It compares the two methodologies of qualitative decision making i.e. ISM and Fuzzy ISM methodologies for establishing the interrelationship amongst them.
\end{abstract}

\section{Keywords}

Social media marketing; AEC industry; Metrics; Social media metrics; ISM methodology

\section{INTRODUCTION}

Very few AEC firms use Google+. This is despite the fact that Google+ pages appear in search results for $30 \%$ of brand term searches for brands with G+ pages . Social media will make or break your online marketing. $75 \%$ of prospective clients and employees check out your social media presence. Many AEC firms talk the talk about using social media but few actually implement it to the extent where they can actively engage their audience on the social media platform as well as motivate their employees for more social engagement. This not only amplifies the online presence of the company as well as provides a second measure of authenticity to a welldeveloped social media action plan.

Targeted email marketing is also becoming popular amongst AEC firms as part of social media marketing. The Construction Marketing Association reports that 75 percent of firms in the industry are planning to increase their spending in email marketing. Without a doubt, email is still the easiest way to make a direct connection with clients and potential customers, and it provides an opportunity to present targeted information in a personalized format.

\subsection{Key characteristics of social media marketing}

1.1.1 Writing content : Leading marketers of today emphasized on the importance and quality of website content. Writing of exceptional content require a specialist . Luckily, construction is an industry with many niches and people are interested in finding or exploring new and upcoming trends so that they should be the innovators in setting them. As a matter of interest, there could be a possibility that people might be interested in finding about the common problems foreign vendors face while transporting large freight at a local site.

1.1.2 Publish your content on LinkedIn : One platform people underrate for building leads is LinkedIn. The environment encourages professional engagement and thoughtful comments, while the site allows you to target the audience you want. LinkedIn complements your website and Facebook page, but remember that articles longer than three paragraphs are best for their publishing platform. For shorter content use the status update - and make it digestible.

1.1.3 Create a social media group: In China, WeChat is ideal for work and social groups. It fosters a golden ratio of purpose (you can only join a group by invitation) and casualness (the groups look like chat rooms). For business, they tend to be professional, friendly, and active.

1.1.4 Develop micro-partnerships with other businesses Influencer marketing is selling your product via an industry or community leader. For example in India , Amitabh Bachchan is quite popular.

1.1.5 Catalog on platforms for builders, developers, and architects : Sites like SpecifiedBy, ArchiExpo and Architonic have changed how architects and builders search and specify products. They also make marketing and networking much easier around the globe.

1.1.6 Use virtual reality : While virtual reality is a bit expensive, it is manageable with hiring production companies and make filming on your own.

1.1.7 Find the right specialists : Sometimes you have to know when to call the professionals. For example, you can do the basics of SEO on your own with a plugin like Yoast. But if you want a unique web presence, you need specialists and firms that create leading SEO and content strategies.

1.1.8 Track your campaigns : All these digital marketing strategies take time. Some of them, like content writing, can take a lot of time. Tracking your digital marketing campaigns is important. Hubspot is a popular platform for marketing. Google Analytics has its own courses for users.

1.1.9 Websites need to be interactive, : Content and media rich, viral and shareable in order to compete in this mobile, social world : Digital media marketing helps Architecture, Engineering, and Construction firms showcase their projects and expertise to position their firm for maximum exposure. The constantly-connected audience seeks websites that are information-rich, functional and valuable in addressing their needs.

Paper is arranged as follows : Section 2 deals with literature review. Section 3 presents the ISM methodology and section 4 with case example. Finally, the paper is concluded in section 5 . 


\section{LITERATURE REVIEW : AEC MARKETING METRICS [1-7]}

Many $\mathrm{A} / \mathrm{E} / \mathrm{C}$ firms suffer from invisible experts, and find themselves being disrupted by competitors who may appear more experienced than they actually are. The good news is that more and more firms are realizing the value of efforts to drive visibility, and how those efforts affect the perception of overall reputation. Accountability is a key to lasting impact and a sustainable program. If a marketing strategy is not measurable and impact is not demonstrated consistently, it will eventually be dialed back as wasteful overhead.

\subsection{Key managerial research questions regarding tracking metrics}

Q-1 : Are your metrics subjective?

Q-2 : Are the metrics relevant to stakeholder issues in terms of its growth, quality and profitability? What is more important to you?

\section{Q-3 : Can you report on them regularly?}

Q-4 : Are the metrics easy to access?

\subsection{Metrics for socializing AEC firms}

Following are some of the common metrics used by AEC firms to track their social progress.

2.2.1 Brand Awareness and Visibility (BAV): These are considered the top two metrics by high growth aspiring firms. Overall website traffic is a great way to get a handle on brand awareness.

2.2.2 good understanding of website traffic (UWT) : Understanding web traffic and its sources will not only inform adjustments to your SEO strategy, social media and other related efforts - it will help stakeholders understand the connection these efforts have to broader goals.

2.2.3 Social Media Engagement (SME) : Buyers are using social media to determine and judge just how much expertise your firm really has. So, tracking social media followers by platform is a powerful way to understand the quality of your visibility and how relevant prospects are interested in connecting with your firm.

2.2.4 Lead Generation and Conversion (LGC): Measuring form fills, phone calls and direct emails requesting a conversation will help your team understand how strong the inbound leads coming your way really are and what results they produce. This may affect the lead generation and conversion positively and prevent the leads falling off too early in the engagement process.

2.2.5 Email list Size (EMS): These can be an effective way to nurture leads and measure conversion. Your email list size is a good indicator of visibility and therefore the building list of a marketing program with interesting and influential folks who have interacted with your firm could be enhancing. These may lead to higher engagement on the visitor's side.

2.2.6 Email open Rate (EOR) : Email open rate helps in tracking the number of people actually opens and read the emails you send. Consistent tracking of EOR therefore can help keeping the social marketing campaigns on target.

2.2.7 Click-through Rate (CTR): Your click-through rate tells you how appealing a particular email offer is by revealing the percentage of folks who were compelled to take action.
2.2.8 Proposals out (PO): Is your program leading prospects to requests for proposals? What does the overall pipeline look like ? Monitor this conversion by tracking the number of proposals and their dollar value.

2.2.9 Proposal wins (PO) : it determines the number of wins your marketing proposal achieve. This includes the weekly and monthly tracking of new client proposals versus existing client proposals. Apart from these the weekly or monthly number and cumulative dollar value are common win rate metrics.

2.2.10 Revenue/Sales goals (R/SG): While not exactly a measure of your firm's marketing success, revenue or sales goals should be the cornerstone of your firm's marketing plan and strategy. Related to this is the dollar volume of work sold. Only $71 \%$ of all firms track the dollar volume of work sold and only $33 \%$ share this information with marketing staff.

2.2.11 New/repeat client Ratio (N/RCR): Being able to know who you are selling to the most gives you the ability to tweak your marketing strategies to optimize for specific goals.

2.2.12 Proposal hit Rate (PHR): Fast-growth firms submitted $53 \%$ more proposals than the average firm. Total number of contacts in the CRM database or contact mailing list. How many people receive your marketing messages? Quality is critical, but volume is important too.

2.2.13 Website Analytics (WA)/ Social media statistics (SMS) : All the statistics relating to your website. According to Zweig Group's 2016 Marketing Survey, the average number of unique visits per week in this industry is only around 750. Know your website bounce rate and average length of a page visit. Statistics such as followers, engagement, and overall impressions. This is one area where constant growth is possible. Take some time to understand your current social media presence. Then set goals and achieve them.

2.2.14 Qualified leads (QL): Qualified leads via each marketing channel and leads that result in jobs. While this can be hard to measure, do your best, then spend money on the things that are bringing in the most money.

\section{INTERPRETIVE STRUCTURAL MODELLING METHODOLOGY}

Interpretive structural modelling methodology or ISM [8] is a known technique to map the relationships amongst the relevant elements as per decision maker's problems in a hierarchical manner. Starting with the identification of elements, it proceeds with establishing the contextual relationships between elements (by examining them in pairs ) and move on towards developing the structural selfinteraction (SSIM) matrix using VAXO [8] and then initial reachability matrix and final reachability matrix and rearranging the elements in topological order using the level partition matrices. A Mic-Mac analysis is performed afterwards which categorize the variables as per the driving and dependence power in to autonomous, dependent, driver and linkage category. Finally, a diagraph can be obtained.

\section{CASE EXAMPLE}

The 14 metrics which have been described above has been further studied with the help of ISM methodology for the possible inter-relationships amongst them . These metrics are Brand awareness and visibility (BAV) ; Understanding website traffic (UWT); Social media engagement (SME); Lead generation \& conversion (LGC); Email list size (ELS); 
Email open rate (EOR); Click through rate (CTR); Proposals out (PO) ; Proposal wins (PW); Revenue / Sales goals (R/SG); New / Repeat Client ratio (NCR); Proposal hit rate (PHR); Website Analytics (WA); Qualify Leads (QL) and Social media Statistics (SMS)

Explanation : Smaller email list size could lead to more website traffic as users are more interested in exploring website rather than communicating through email. Email open rate as well as click through rate help in understanding website traffic. Social media engagement may lead to understanding website traffic, lead generation increased revenue increase proposal hit rate and high ratio on part of new and repeat clients. It also helps in understanding social media statistics and in fact contribute towards it. Website analytics will also help in generating leads . Knowledge about website analytics helps in contributing towards email open rate, click through rate . more the proposals are out the more the chance of its win and therefore more the hit rate of the proposal . understanding social media statistics could contribute towards qualifying leads, understanding website traffic and also in turn leads to presenting more proposals for its possible acceptance in web market . Email list size , email open rate etc. are all components of social media statistics and website analytics. Qualifying leads may motivate to bring more proposals. EOR could lead to ctr as the more you like the emails of the sender, the more you would be interested in clicking on his website

\subsection{Structural self- interaction matrix (SSIM)}

\begin{tabular}{|c|c|c|c|c|c|c|c|c|c|c|c|c|c|c|c|}
\hline $\begin{array}{c}\text { S. } \\
\text { No. }\end{array}$ & Barriers & 1 & 2 & 3 & 4 & 5 & 6 & 7 & 8 & 9 & 10 & 11 & 12 & 13 & 14 \\
\hline & & BAV & UWT & SME & LGC & ELS & EOR & CTR & PO & PW & R/SG & CR & PHR & WA & QL \\
\hline 1 & BAV & & V & A & V & X & V & V & V & V & V & V & V & V & V \\
\hline 2 & UWT & & & A & X & A & A & X & X & X & V & V & V & A & X \\
\hline 3 & SME & & & & V & V & V & V & V & V & V & V & V & V & V \\
\hline 4 & LGC & & & & & A & A & A & V & V & V & V & V & A & V \\
\hline 5 & ELS & & & & & & V & V & V & V & V & V & V & V & V \\
\hline 6 & EOR & & & & & & & V & V & V & V & V & V & V & V \\
\hline 7 & CTR & & & & & & & & V & V & V & V & V & V & V \\
\hline 8 & PO & & & & & & & & V & V & V & V & V & V \\
\hline 9 & PW & & & & & & & & & & V & V & V & V & V \\
\hline 10 & R/SG & & & & & & & & & & A & A & A & A \\
\hline 11 & CR & & & & & & & & & & & & V & V & A \\
\hline 12 & PHR & & & & & & & & & & & & & V & V \\
\hline 13 & WA & & & & & & & & & & & & & A \\
\hline 14 & QL & & & & & & & & & & & & & \\
\hline
\end{tabular}

Fig 1: SSIM matrix for pair wise relationship amongst barriers

\begin{tabular}{|c|c|c|c|c|c|c|c|c|c|c|c|c|c|c|c|}
\hline $\begin{array}{c}\text { S. } \\
\text { No. }\end{array}$ & Barriers & 1 & 2 & 3 & 4 & 5 & 6 & 7 & 8 & 9 & 10 & 11 & 12 & 13 & 14 \\
\hline & & BAV & UWT & SME & LGC & ELS & EOR & CTR & PO & PW & R/SG & CR & PHR & WA & QL \\
\hline 1 & BAV & 1 & 1 & 0 & 1 & 1 & 1 & 1 & 1 & 1 & 1 & 1 & 1 & 1 & 1 \\
\hline 2 & UWT & 0 & 1 & 0 & 1 & 1 & 1 & 1 & 1 & 1 & 1 & 1 & 1 & 0 & 1 \\
\hline 3 & SME & 1 & 1 & 1 & 1 & 1 & 1 & 1 & 1 & 1 & 1 & 1 & 1 & 1 & 1 \\
\hline 4 & LGC & 0 & 1 & 0 & 1 & 0 & 0 & 0 & 1 & 1 & 1 & 1 & 1 & 0 & 1 \\
\hline 5 & ELS & 1 & 1 & 0 & 0 & 1 & 1 & 1 & 1 & 1 & 1 & 1 & 1 & 1 & 1 \\
\hline 6 & EOR & 0 & 1 & 0 & 0 & 0 & 1 & 1 & 1 & 1 & 1 & 1 & 1 & 1 & 1 \\
\hline 7 & CTR & 0 & 1 & 0 & 0 & 0 & 0 & 1 & 1 & 1 & 1 & 1 & 1 & 1 & 1 \\
\hline 8 & PO & 0 & 1 & 0 & 0 & 0 & 0 & 0 & 1 & 1 & 1 & 1 & 1 & 1 & 1 \\
\hline 9 & PW & 0 & 1 & 0 & 0 & 0 & 0 & 0 & 0 & 1 & 1 & 1 & 1 & 1 & 1 \\
\hline 10 & R/SG & 0 & 0 & 0 & 0 & 0 & 0 & 0 & 0 & 0 & 1 & 1 & 1 & 1 & 1 \\
\hline 11 & CR & 0 & 0 & 0 & 0 & 0 & 0 & 0 & 0 & 0 & 1 & 1 & 1 & 1 & 0 \\
\hline 12 & PHR & 0 & 0 & 0 & 0 & 0 & 0 & 0 & 0 & 0 & 1 & 1 & 1 & 1 & 1 \\
\hline 13 & WA & 0 & 1 & 0 & 0 & 0 & 0 & 0 & 0 & 0 & 1 & 1 & 0 & 1 & 0 \\
\hline 14 & QL & 0 & 1 & 0 & 0 & 0 & 0 & 0 & 0 & 0 & 1 & 1 & 0 & 1 & 1 \\
\hline
\end{tabular}

Fig 2: Initial reachability matrix 


\begin{tabular}{|c|c|c|c|c|c|c|c|c|c|c|c|c|c|c|c|c|}
\hline $\begin{array}{c}\text { S. } \\
\text { No. }\end{array}$ & Barriers & 1 & 2 & 3 & 4 & 5 & 6 & 7 & 8 & 9 & 10 & 11 & 12 & 13 & 14 & D.P \\
\hline & & BAV & UWT & SME & LGC & ELS & EOR & CTR & PO & PW & R/SG & CR & PHR & WA & QL & \\
\hline 1 & BAV & 1 & 1 & 0 & 1 & 1 & 1 & 1 & 1 & 1 & 1 & 1 & 1 & 1 & 1 & 13 \\
\hline 2 & UWT & 0 & 1 & 0 & 1 & 1 & 1 & 1 & 1 & 1 & 1 & 1 & 1 & 1 & 1 & 12 \\
\hline 3 & SME & 1 & 1 & 1 & 1 & 1 & 1 & 1 & 1 & 1 & 1 & 1 & 1 & 1 & 1 & 14 \\
\hline 4 & LGC & 0 & 1 & 0 & 1 & 1 & 1 & 1 & 1 & 1 & 1 & 1 & 1 & 1 & 1 & 12 \\
\hline 5 & ELS & 1 & 1 & 0 & 0 & 1 & 1 & 1 & 1 & 1 & 1 & 1 & 1 & 1 & 1 & 12 \\
\hline 6 & EOR & 0 & 1 & 0 & 0 & 0 & 1 & 1 & 1 & 1 & 1 & 1 & 1 & 1 & 1 & 10 \\
\hline 7 & CTR & 0 & 1 & 0 & 0 & 0 & 0 & 1 & 1 & 1 & 1 & 1 & 1 & 1 & 1 & 9 \\
\hline 8 & PO & 0 & 1 & 0 & 0 & 0 & 0 & 0 & 1 & 1 & 1 & 1 & 1 & 1 & 1 & 8 \\
\hline 9 & PW & 0 & 1 & 0 & 0 & 0 & 0 & 0 & 0 & 1 & 1 & 1 & 1 & 1 & 1 & 7 \\
\hline 10 & R/SG & 0 & 0 & 0 & 0 & 0 & 0 & 0 & 0 & 0 & 1 & 1 & 1 & 1 & 1 & 9 \\
\hline 11 & CR & 0 & 0 & 0 & 0 & 0 & 0 & 0 & 0 & 0 & 1 & 1 & 1 & 1 & 0 & 4 \\
\hline 12 & PHR & 0 & 0 & 0 & 0 & 0 & 0 & 0 & 0 & 0 & 1 & 1 & 1 & 1 & 1 & 5 \\
\hline 13 & WA & 0 & 1 & 0 & 0 & 0 & 0 & 0 & 0 & 0 & 1 & 1 & 1 & 1 & 1 & 5 \\
\hline 14 & QL & 0 & 1 & 0 & 0 & 0 & 0 & 0 & 0 & 0 & 1 & 1 & 1 & 1 & 1 & 5 \\
\hline & De.P & 3 & 11 & 1 & 4 & 5 & 6 & 7 & 8 & 9 & 14 & 14 & 14 & 14 & 13 & \\
\hline
\end{tabular}

Fig 3 : Final reachability matrix

D.P : Driving power ; De.P : dependence power

\subsection{Level Partition}

From the final reachability matrix, reachability and final antecedent set for each factor are found. The element for which the reachability and intersection sets are same are the top-level element in the ISM hierarchy. After the identification of top level element, it is separated out from the other elements and the process continues for next level of elements. Reachability set, antecedent set, intersection set along with different level for elements have been shown below in table 4.3.1 to table 4.3.9.

Table 4.3.1: Iteration I

\begin{tabular}{|c|c|c|c|c|}
\hline S.No. & $\begin{array}{l}\text { Reachabili } \\
\text { ty set }\end{array}$ & Antecedent set & $\begin{array}{c}\text { Intersec } \\
\text { tion set }\end{array}$ & Level \\
\hline 1. & $\begin{array}{c}10,11,12,1 \\
3\end{array}$ & $\begin{array}{c}1,2,3,4,5,6,7,8,9 \\
10,11,12,13,14\end{array}$ & $\begin{array}{c}10,11,12, \\
13\end{array}$ & \multirow{8}{*}{ I } \\
\hline 2. & $\begin{array}{c}10,11,12,1 \\
3,14\end{array}$ & $\begin{array}{c}1,2,3,4,5,6,7,8,9 \\
10,12,13,14\end{array}$ & $\begin{array}{c}10,12,13, \\
14\end{array}$ & \\
\hline 3. & $\begin{array}{c}2,10,11,12, \\
13,14\end{array}$ & $\begin{array}{c}1,2,3,4,5,6,7,8,9 \\
13,14\end{array}$ & $\begin{array}{c}2,11,13,1 \\
4\end{array}$ & \\
\hline 4. & $\begin{array}{c}2,9,10,11,1 \\
2,13,14\end{array}$ & $1,2,3,4,5,6,7,8,9$ & 2,9 & \\
\hline 5. & $\begin{array}{c}2,8,9,10,11 \\
, 12,13,14\end{array}$ & $1,2,3,4,5,6,7,8$ & 2,8 & \\
\hline 6. & $\begin{array}{c}2,7,8,9,10 \\
11,12,13 \\
14\end{array}$ & $1,2,3,4,5,6,7$ & 2,7 & \\
\hline 7. & $\begin{array}{c}2,6,7,8,9 \\
10,11,12 \\
13,14\end{array}$ & $1,2,3,4,5,6$ & 2,6 & \\
\hline 8. & $\begin{array}{c}2,5,6,7,8,9, \\
10,11,12,1\end{array}$ & $1,2,3,4,5$ & 2,5 & \\
\hline
\end{tabular}

\begin{tabular}{|c|c|c|c|c|}
\hline & 3,14 & & \\
\cline { 1 - 4 } 9. & $2,4,5,6,7,8$, & $1,2,3,4$ & 2,4 & \\
& $9,10,11$, & & & \\
& $12,13,14$ & & & \\
\hline
\end{tabular}

Table 4.3.2: Iteration II

\begin{tabular}{|c|c|c|c|c|}
\hline S.No. & $\begin{array}{c}\text { Reachabili } \\
\text { ty set }\end{array}$ & Antecedent set & $\begin{array}{c}\text { Intersec } \\
\text { tion set }\end{array}$ & Level \\
\hline 2. & 14 & $\begin{array}{c}1,2,3,4,5,6,7,8,9 \\
14\end{array}$ & 14 & \multirow{8}{*}{ II } \\
\hline 3. & 2,14 & $\begin{array}{c}1,2,3,4,5,6,7,8,9 \\
14\end{array}$ & 2,14 & \\
\hline 4. & $2,9,14$ & $1,2,3,4,5,6,7,8,9$ & 2,9 & \\
\hline 5. & $2,8,9,14$ & $1,2,3,4,5,6,7,8$ & 2,8 & \\
\hline 6. & $2,7,8,9,14$ & $1,2,3,4,5,6,7$ & 2,7 & \\
\hline 7. & $\begin{array}{c}2,6,7,8,9,1 \\
4\end{array}$ & $1,2,3,4,5,6$ & 2,6 & \\
\hline 8. & $\begin{array}{c}2,5,6,7,8,9, \\
14\end{array}$ & $1,2,3,4,5$ & 2,5 & \\
\hline 9. & $\begin{array}{c}2,4,5,6,7,8 \\
9,14\end{array}$ & $1,2,3,4$ & 2,4 & \\
\hline
\end{tabular}

Table 4.3.3: Iteration III

\begin{tabular}{|c|c|c|c|c|}
\hline S.No. & $\begin{array}{c}\text { Reachabili } \\
\text { ty set }\end{array}$ & Antecedent set & $\begin{array}{c}\text { Intersec } \\
\text { tion set }\end{array}$ & Level \\
\hline 3. & $\mathbf{2}$ & $1,2,3,4,5,6,7,8,9$ & 2 & \\
\hline 4. & 2,9 & $1,2,3,4,5,6,7,8,9$ & 2,9 & \\
\cline { 1 - 4 } 5. & $2,8,9$ & $1,2,3,4,5,6,7,8$ & 2,8 & \\
\hline
\end{tabular}




\begin{tabular}{|c|c|c|c|c|}
\hline 6. & $2,7,8,9$ & $1,2,3,4,5,6,7$ & 2,7 & \multirow{4}{*}{ III } \\
\hline 7. & $2,6,7,8,9$ & $1,2,3,4,5,6$ & 2,6 & \\
\hline 8. & $2,5,6,7,8,9$ & $1,2,3,4,5$ & 2,5 & \\
\hline 9. & $\begin{array}{c}2,4,5,6,7,8, \\
9\end{array}$ & $1,2,3,4$ & 2,4 & \\
\hline
\end{tabular}

Table 4.3.4: Iteration IV

\begin{tabular}{|c|c|c|c|c|}
\hline S.No. & $\begin{array}{l}\text { Reachabili } \\
\text { ty set }\end{array}$ & Antecedent set & $\begin{array}{c}\text { Intersec } \\
\text { tion set }\end{array}$ & Level \\
\hline 4. & 9 & $1,2,3,4,5,6,7,8,9$ & 2,9 & \multirow{7}{*}{ IV } \\
\hline 5. & 8,9 & $1,2,3,4,5,6,7,8$ & 2,8 & \\
\hline 6. & $7,8,9$ & $1,2,3,4,5,6,7$ & 2,7 & \\
\hline 7. & $6,8,9$ & $1,2,3,4,5,6$ & 2,6 & \\
\hline 8. & $5,6,8,9$ & $1,2,3,4,5$ & 2,5 & \\
\hline 9. & $4,5,6,7,8,9$ & $1,2,3,4$ & 2,4 & \\
\hline 10. & $\begin{array}{c}1,4,5,6,7,8 \\
9\end{array}$ & 1,3 & 1 & \\
\hline
\end{tabular}

Table 4.3.5: Iteration $\mathrm{V}$

\begin{tabular}{|c|c|c|c|c|}
\hline S.No. & $\begin{array}{l}\text { Reachabili } \\
\text { ty set }\end{array}$ & Antecedent set & $\begin{array}{c}\text { Intersec } \\
\text { tion set }\end{array}$ & Level \\
\hline 5. & 8 & $1,2,3,4,5,6,7,8$ & 2,8 & \multirow{7}{*}{$\mathbf{V}$} \\
\hline 6. & 7,8 & $1,2,3,4,5,6,7$ & 2,7 & \\
\hline 7. & $6,7,8$ & $1,2,3,4,5,6$ & 2,6 & \\
\hline 8. & $5,6,7,8$ & $1,2,3,4,5$ & 2,5 & \\
\hline 9. & $4,5,6,7,8$ & $1,2,3,4$ & 2,4 & \\
\hline 10. & $1,4,5,6,7,8$ & 1,3 & 1 & \\
\hline 11. & $\begin{array}{c}1,3,4,5,6,7 \\
8\end{array}$ & 3 & 3 & \\
\hline
\end{tabular}

Table 4.3.6: Iteration VI

\begin{tabular}{|c|c|c|c|c|}
\hline S.No. & $\begin{array}{c}\text { Reachabili } \\
\text { ty set }\end{array}$ & Antecedent set & $\begin{array}{c}\text { Intersec } \\
\text { tion set }\end{array}$ & Level \\
\hline 6. & 7 & $1,2,3,4,5,6,7$ & 2,7 & \multirow{6}{*}{ VI } \\
\hline 7. & 6,7 & $1,2,3,4,5,6$ & 2,6 & \\
\hline 8. & $5,6,7$ & $1,2,3,4,5$ & 2,5 & \\
\hline 9. & $4,5,6,7$ & $1,2,3,4$ & 2,4 & \\
\hline 10. & $1,4,5,6,7$ & 1,3 & 1 & \\
\hline 11. & $1,3,4,5,6,7$ & 3 & 3 & \\
\hline
\end{tabular}

Table 4.3.7: Iteration VII

\begin{tabular}{|c|c|c|c|c|}
\hline S.No. & $\begin{array}{c}\text { Reachabili } \\
\text { ty set }\end{array}$ & Antecedent set & $\begin{array}{c}\text { Intersec } \\
\text { tion set }\end{array}$ & Level \\
\hline 7. & $\mathbf{6}$ & $1,2,3,4,5,6$ & 6 & \\
\hline 8. & 5,6 & $1,2,3,4,5$ & 5 & \\
\hline
\end{tabular}

\begin{tabular}{|c|c|c|c|c|}
\hline 9. & $4,5,6$ & $1,2,3,4$ & 4 & \multirow{2}{*}{ VII } \\
\cline { 1 - 4 } 10. & $1,4,5,6$ & 1,3 & 1 & \\
\cline { 1 - 3 } & & & 3 & \\
\hline
\end{tabular}

Table 4.3.8: Iteration VIII

\begin{tabular}{|c|c|c|c|c|}
\hline S.No. & $\begin{array}{c}\text { Reachabili } \\
\text { ty set }\end{array}$ & Antecedent set & $\begin{array}{c}\text { Intersec } \\
\text { tion set }\end{array}$ & Level \\
\hline 8. & $\mathbf{5}$ & $1,3,4,5$ & 5 & \\
\hline 9. & $4,5,6$ & $1,3,4$ & 4 & \multirow{2}{*}{ VIII } \\
\cline { 1 - 4 } 10. & $1,4,5,6$ & 1,3 & 1 & \\
\hline 11. & $1,3,4,5,6$ & 3 & 3 & \\
\hline
\end{tabular}

Table 4.3.9: Iteration IX

\begin{tabular}{|c|c|c|c|c|}
\hline S.No. & $\begin{array}{c}\text { Reachabili } \\
\text { ty set }\end{array}$ & Antecedent set & $\begin{array}{c}\text { Intersec } \\
\text { tion set }\end{array}$ & Level \\
\hline 9. & $\mathbf{4}$ & $1,3,4$ & 4 & \\
\cline { 1 - 4 } 10. & 1,4 & 1,3 & 1 & \multirow{2}{*}{ IX } \\
\hline 11. & $1,3,4$ & 3 & 3 & \\
\hline
\end{tabular}

Table 4.3.10: Iteration $X$

\begin{tabular}{|c|c|c|c|c|}
\hline S.No. & $\begin{array}{c}\text { Reachabili } \\
\text { ty set }\end{array}$ & Antecedent set & $\begin{array}{c}\text { Intersec } \\
\text { tion set }\end{array}$ & Level \\
\hline 10. & $\mathbf{1}$ & 1,3 & 1 & \multirow{2}{*}{$\mathrm{X}$} \\
\hline 11. & 1,3 & 3 & 3 & \\
\hline
\end{tabular}

Table 4.3.11: Iteration XI

\begin{tabular}{|c|c|c|c|c|}
\hline S.No. & $\begin{array}{c}\text { Reachabili } \\
\text { ty set }\end{array}$ & Antecedent set & $\begin{array}{c}\text { Intersec } \\
\text { tion set }\end{array}$ & Level \\
\hline 11. & 3 & 3 & 3 & XI \\
\hline
\end{tabular}

\subsection{Driving power - Dependence Diagram}

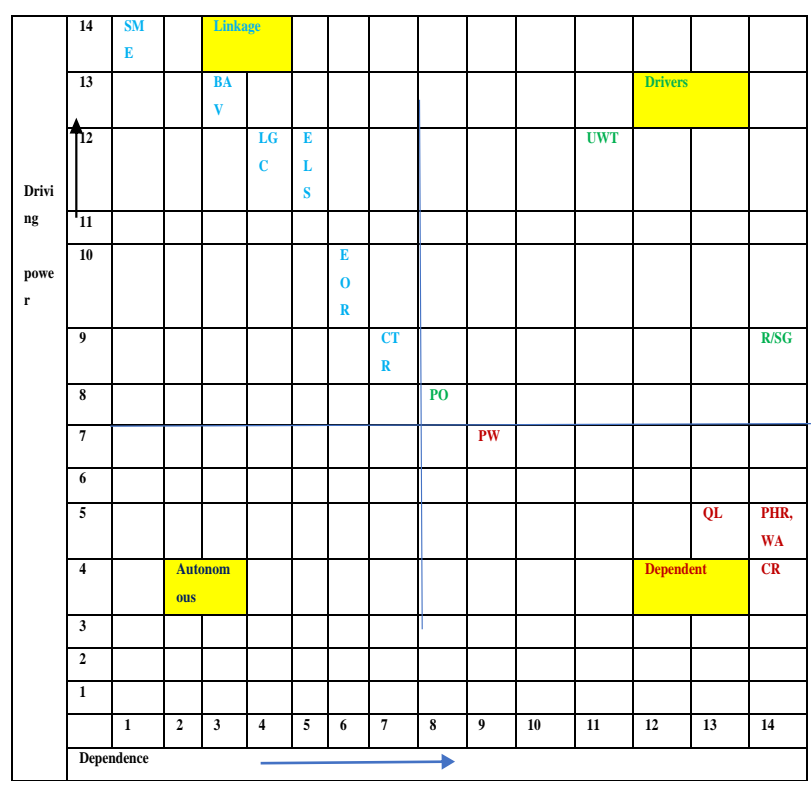




\subsection{ISM Diagraph}

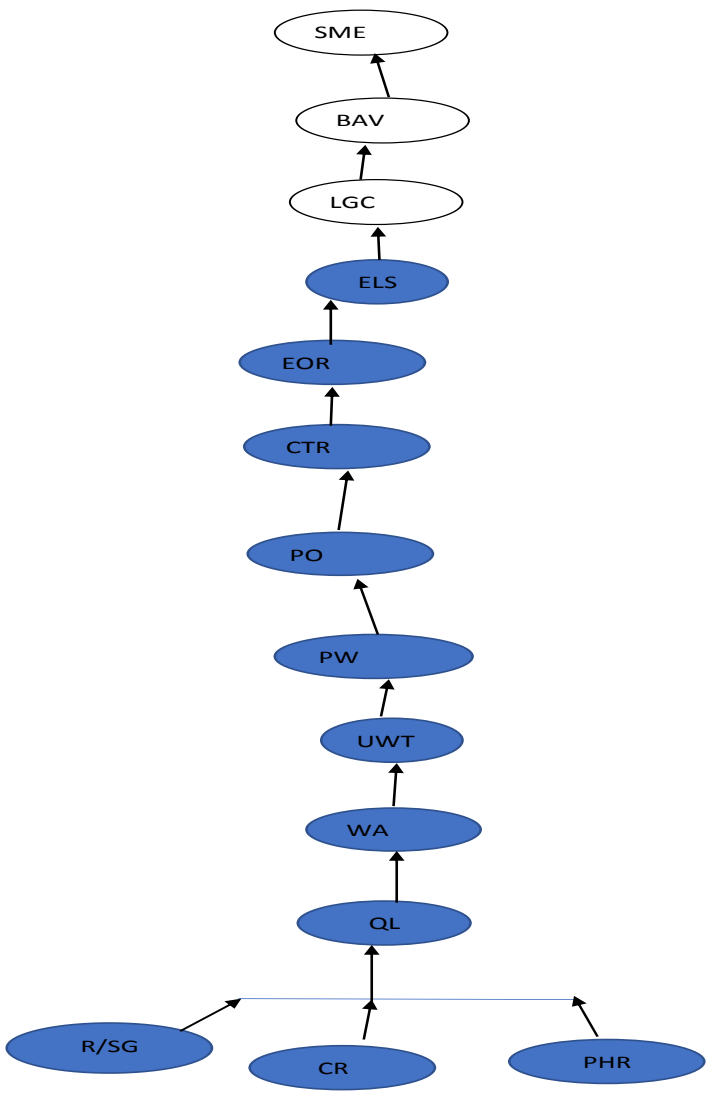

Fig : ISM Diagraph

\section{FUTURE DIRECTIONS}

Present research work makes use of metrics to assess social media with respect to AEC industry. The concept could further be extended to study the interrelationship amongst metrics for a particular case on health care construction industry or an educational institution construction industry.

\section{ACKNOWLEDGEMENTS}

Authors are thankful to Prof. S.P Singh from DMS , IIT Delhi for disseminating the knowledge about ISM methodology which has helped the co-author Remica Aggarwal in preparing this manuscript. Remica Aggarwal extends her sincere regards to Computer Science Department (CSD), BITS Pilani, Pilani campus for giving her the opportunity to attend the course on AEC industry and its related design software.

\section{REFERENCES}

[1] https://www.designingbuildings.co.uk/wiki/Digital_mark eting_for_the_construction_industry

[2] https://zweiggroup.com/2017/03/13/marketing-metricsfor-the-aec-industry/

[3] https://aec-marketing.com/blog/2017/6/13/top-fivetrends-in-aec-marketing

[4] http://go.psmj.com/blog/a/e/c-marketing-metrics-thatmatter-in-2017

[5] https://www.smallscreenproducer.com/digital-mediamarketing-is-changing-the-aec-industry/

[6] https://academy.archistar.ai

[7] Abdirad, H. and Pishdad-Bozorgi, P. 2014. Computing in Civil and Building Engineering, ASCE 2014, pp 496510 .

[8] Warfield, J.N. 1974. Developing interconnection matrices in structural modelling, in the proceedings of IEEE Transactions on System, Man, and Cybernetics, SMC, 4 (1), 81-87. 